https://doi.org/10.19195/0137-1150.173.22

Data przesłania artykułu: 5.09.2019

Data akceptacji artykułu: 21.02.2020

\title{
Rekonstruowanie pamięci. Problemy udostępniania ukraińskiej prozy lat dwudziestych i trzydziestych XX wieku polskiemu odbiorcy
}

Celem niniejszego artykułu jest wskazanie podstawowych problemów wydawniczych, ujawniających się przy próbach przybliżenia polskiemu odbiorcy ukraińskiej prozy lat dwudziestych i trzydziestych XX wieku. „Problemy wydawnicze" rozumiem przy tym szeroko, zgodnie z polem badawczym zakreślonym przez socjologów literatury ${ }^{1}$ : od wpływu kwestii estetycznych i ideologicznych na wybory dokonywane przez redaktorów, tłumaczy, wydawców i czytelników aż po wpływ mechanizmów finansowania procesów przekładowych i wydawniczych na powstawanie i dostępność przekładów.

Historia i polityka sprawiły, że literatura ukraińska wskazanego okresu jeszcze do niedawna była dostępna w polskich przekładach gorzej niż wybiórczo, mimo że był to okres intensywnego rozkwitu kultury ukraińskiej: na Ukrainie radzieckiej pisarze i artyści, wykorzystując oficjalną politykę korienizacji ${ }^{2}$, rozwijają fenomen, który później, w wyniku represji połowy lat trzydziestych, zyska nazwę „rozstrzelanego odrodzenia”. Równolegle ukraińskie życie literackie i artystyczne rozwijało się na ziemiach II Rzeczypospolitej. Po obu stronach Zbrucza powstawały podstawowe dla zrozumienia dwudziestowiecznej kultury ukraińskiej opowiadania, nowele i powieści. Odzwierciedlają one modernistyczne i modernizacyjne tendencje epoki, wchodzą w dialog z tekstami kultur sąsiedzkich i kultu-

${ }^{1}$ Por. np. Socjologia literatury. Antologia, red. G. Jankowicz, M. Tabaczyński, Kraków 2015.

2 Korienizacja to proces zwiększania udziału miejscowej ludności w sowieckim aparacie republik związkowych i autonomicznych oraz wprowadzania lokalnego języka do użytku oficjalnego w latach dwudziestych XX wieku; początkowo proces ten przyczynił się do rozwoju kultur narodowych, od 1928 roku był ograniczany. 
ry światowej, a jednocześnie podejmują dyskusję z ukraińską tradycją i historią. Co równie istotne - znajomość tekstów tego okresu ma wielkie znaczenie dla zrozumienia współczesnych zjawisk i tendencji w kulturze ukraińskiej.

Ponieważ jest to pierwszy ogólny przegląd sytuacji, w kolejnych częściach artykułu: 1. omówię główne uwarunkowania historyczne, kulturowe i polityczne, które przyczyniły się do powstania zaległości, odwołując się także do wcześniejszych ustaleń badaczy; 2. zaprezentuję najnowsze polskie projekty wydawnicze, które mają szansę wprowadzić nieco równowagi do zachwianej perspektywy polskiego postrzegania ukraińskiego dojrzałego modernizmu; 3. zwrócę uwagę na bieżące problemy występujące przy pracy nad udostępnianiem polskiemu odbiorcy ukraińskiej prozy ${ }^{3}$ pierwszej połowy XX wieku. Co może się wydawać zaskakujące, będą to w szczególności problemy wynikające z zasad organizacji, finansowania i rozliczania projektów, obowiązujących w polskich badaniach naukowych.

\section{Zaległości: powody}

Niedostępność podstawowych tekstów prozatorskich ukraińskiego modernizmu w przekładach polskich jest związana zarówno z problemami własnej, ukraińskiej refleksji historycznoliterackiej, jak i z problemami polskiej recepcji.

Po drugiej wojnie światowej dzieła niezgodne z wizją rządzącej partii komunistycznej zostały wyparte $\mathrm{z}$ oficjalnej ukraińskiej pamięci zbiorowej. Teksty literackie usunięto z obiegu, a posiadanie dawniejszych wydań mogło przyczynić się do oskarżenia ich właściciela o „burżuazyjny nacjonalizm”. Wielu pisarzy skazano też na zniknięcie w sferze symbolicznej: przez kilkadziesiąt kolejnych lat nie wymieniano nawet ich nazwisk. Siłą rzeczy niemożliwa była rodzima refleksja krytyczna nad tą częścią ukraińskiej literatury, a odczytanie emigracyjne, choć w wielu przypadkach cenne do dziś, było, po pierwsze, wybiórcze, po drugie naznaczone cieniem martyrologii, po trzecie wreszcie - do lat dziewięćdziesiątych pozbawione realnego wpływu na „krajowy” odbiór literatury tego okresu ${ }^{4}$.

Po roku 1991 literatura lat dwudziestych i trzydziestych wraca do ukraińskiego „krajowego" obiegu wydawniczego. Jest to jednak proces w znacznym stopniu chaotyczny i wybiórczy, do czego przyczyniły się problemy organizacyjne i wydawnicze, a także ograniczone możliwości poddania refleksji naukowej i krytycznej tak złożonego materiału, wymagającego zupełnie nowych w warunkach postradzieckich narzędzi intelektualnych. W naturalny sposób przejęto więc istniejący logiczny i zrozumiały schemat myślenia o tym okresie, wypracowany przez ukraińską

${ }^{3}$ Zaznaczam ponownie, że skupiam się na recepcji tekstów prozatorskich; sytuacja poezji wygląda nieco lepiej, o czym pisała między innymi Ola Hnatiuk; zob. eadem, Острівиі в океані. Про рецепиію украйнської літератури в польській культурі першої половини ХХ століття, [w:] еаdет, Між літературою і політикою. Есеї та інтермедії, Київ 2012, s. 143-166.

${ }^{4}$ Por. analiza sytuacji literatury rosyjskiej B. Żyłko, O klopotach badacza literatury rosyjskiej XX wieku uwag kilka, [w:] Literatura rosyjska XX wieku. Nowe czasy. Nowe problemy, red. G. Bobilewicz-Bryś, A. Drawicz, Warszawa 1992, s. 69-75. 
emigrację. Jak pokazują najnowsze analizy ${ }^{5}$, ta odziedziczona pamięć wymaga jednak rewizji. Najważniejsze, trudne już dziś do usprawiedliwienia deformacje dotyczą dwóch kwestii: po pierwsze, pominięci zostają pisarze galicyjscy; po drugie, $\mathrm{z}$ emigracyjnego pola widzenia niemal całkowicie wypadły pisarki.

Podsumowując, należy przyznać, że problemy własnej, rodzimej refleksji nad historią literatury ukraińskiej omawianego okresu są zrozumiałe. NIemniej, wynikający z tego brak opracowań krytycznych i wydań wzorcowych ogromnie utrudniał potencjalnym zagranicznym wydawcom dotarcie do tych tekstów. Nie jest to oczywiście jedyny powód - z polskiego punktu widzenia nazwijmy go „zewnętrznym” - dla którego polscy czytelnicy długo nie mieli szansy zapoznania się z nimi.

Przegląd problemów, które nazwę „wewnętrznymi”, zacząć wypada od okresu międzywojennego, czyli od wskazania przyczyn niesynchronicznej recepcji literatury ukraińskiej. Znów mamy do czynienia z dwiema grupami tekstów. Literatura Ukrainy radzieckiej była wówczas trudno dostępna, w dodatku często uważana en masse za „komunistyczną” — co dodatkowo komplikowało ogółem trudne polsko-ukraińskie kontakty literackie. Literatura autorów galicyjskich była pozornie bliższa, a na pewno o wiele łatwiej dostępna. Tu jednak nieustanne konflikty polityczne i społeczne stawały na przeszkodzie kontaktom kulturalnym ${ }^{6}$. Powieść Wolyń Ułasa Samczuka ${ }^{7}$, wydana po polsku w 1938 roku, jest raczej wyjątkiem potwierdzającym regułę.

Po 1945 roku nawet „,pojedyncze wyspy na oceanie wrogości”8 zostały wyparte z oficjalnej pamięci i przesłonięte tekstami wydawanymi aż do lat osiemdziesiątych XX wieku przede wszystkim według klucza ideologicznego. W efekcie nawet nowatorskie jak na swoją epokę powieści i opowiadania z nurtu „magicznego realizmu" nie zdołały zmienić nastawienia czytelników, o czym obszerniej i opierając się na konkretnych przykładach, pisała Ola Hnatiuk ${ }^{9}$.

${ }^{5}$ Więcej zob. K. Kotyńska, Na tropie pisarek. Wspótczesny kanon a literatura ukraińska między dwiema wojnami, [w:] Wspólnota wyobrażona. Pisarki Europy Środkowej wobec problemów literackich, spolecznych i politycznych lat 1914-1945, red. G. Borkowska, I. Boruszkowska, K. Nadana-Sokołowska, Warszawa 2017, s. 489-499; O. Hałeta, Historia literatury jako praktyka ponownego czytania, [w:] Wspólnota wyobrażona..., s. 501-508; О. Галета, Від антологіï до онтології: антологія як спосіб репрезентачії української літератури кіния XIX-початку ХХІ століття, Київ 2015, zwłaszcza rozdz. 3. Ідеологія і географiя, s. 205-300. Por. też podstawowe dane statystyczne dotyczące kobiecego pola literackiego Ukrainy radzieckiej lat 1917-1927: P. Krupa, „Na Zachód” i „Z dala od Moskwy”? Publicystyka Mykoły Chwylowego lat 1925-1926. Historia - idee - konteksty, Kraków 2018, s. 454.

6 Więcej zob. Ukraińskie życie kulturalne na ziemiach II Rzeczypospolitej, red. O. Hnatiuk, K. Kotyńska, Warszawa 2002.

${ }^{7}$ U. Samczuk, Wolyń, przeł. T. Hollender, Warszawa 1938.

8 О. Гнатюк, Острівці в океані..., s. 166.

9 О. Гнатюк, Модифікована рецепція. Видавнича практика комуністичної Польщі та образ української культури, [w:] еадет, Між літературою і політикою..., s. 167-186; J. Litwiniuk, Problemy przekładu z literatury ukraińskiej. Z warsztatu tlumacza, „Warszawskie Zeszyty Ukrainoznawcze" 1994, nr 2, s. 201-204. 
W latach 1989-1991 wśród głównych problemów wskazać należy wspomniane nierozpoznanie, ograniczoną infrastrukturę badawczą oraz załamanie wcześniej istniejących mechanizmów wydawniczych.

Trzeba też pamiętać o pozycji literatury ukraińskiej w polskim odbiorze. Z jednej strony już od początku lat dziewięćdziesiątych budowana była stała i ciągle rosnąca obecność literatury i kultury ukraińskiej w Polsce. Następowało to w dużej mierze dzięki osobistemu zaangażowaniu poszczególnych osób, wyrastało z osobistych kontaktów i pozasystemowych inicjatyw lokalnych. W efekcie „młoda” literatura ukraińska była zupełnie nieźle reprezentowana i zyskała grono zainteresowanych odbiorców: przyciągała swoją świeżością, odmiennością, zadziornością. $Z$ drugiej jednak strony to zainteresowanie nie rozciągało się na teksty dawniejsze. Inaczej niż w wypadku literatury rosyjskiej nie istniało przekonanie, że owe dawniejsze dzieła w ogóle istnieją i warto poświęcić im uwagę ${ }^{10}$.

Literatura ukraińska potrzebowała procesu nowego budowania prestiżu. Konflikty i wzajemna nieufność okresu międzywojennego, nieprzekonanie o „historyczności" ukraińskiej kultury (a także długotrwałe nieistnienie odrębnego, niezależnego bytu państwowego, co przy budowaniu prestiżu danej kultury nie pozostaje bez znaczenia) w połączeniu z polityką wydawniczą okresu PRL sprawiły, że najpierw trzeba było polskich czytelników i wydawców przekonać do kultury ukraińskiej w ogóle.

\section{Czas zmian: projekty wydawnicze}

Pierwszy współczesny projekt, którego celem było zaprezentowanie polskiemu czytelnikowi prozy ukraińskiego modernizmu, to antologia Stepowa legenda $(2001)^{11}$. Zawiera ona wybór opowiadań modernistycznych, przy czym modernizm jest tu dość szeroko rozumiany i obejmuje pisarzy od środowiska „Ukraińskiej chaty” i „Młodej muzy” do „rozstrzelanego odrodzenia”. Teksty w większości zostały przetłumaczone na język polski po raz pierwszy, specjalnie do tego wydania (między innymi przez Jerzego Litwiniuka, Tatianę Hołyńską, Olę Hnatiuk) oraz opatrzone obszernym komentarzem historycznoliterackim. Celem tej prezentacji, oprócz zaznajomienia polskich czytelników z literaturą ukraińską wskazanego okresu, było zabranie głosu w toczącej się na przełomie XX i XXI wieku ważnej ukraińskiej dyskusji o periodyzacji procesu literackiego i stanowieniu kanonu literatury ukraińskiej ${ }^{12}$.

Stepowa legenda jest zatem czymś między skryptem akademickim a wyborem opowiadań. Wydana w wydawnictwie naukowym, które słabo radziło sobie w nowej sytuacji rynkowej, trafiła głównie do ukrainistów i slawistów. W tym

10 Por. B. Żyłko, O kłopotach...

11 Stepowa legenda. Antologia ukraińskiej matej formy prozatorskiej lat 1890-1930, red. O. Hnatiuk, L. Szost, Warszawa 2001.

12 Por. np. С. Павличко, Дискурс модернізму в украӥнській літературі, Київ 1997; М. Павлишин, Канон та іконостас, Київ 1997. 
wąskim kręgu stała się jednak punktem wyjścia do dalszych dyskusji, a także rozszerzyła możliwość proponowania tekstów modernistycznych studentom nieznającym języka ukraińskiego.

Jak się bowiem okazało, zmiana systemu politycznego oraz orientacji geopolitycznej miała dla studiów ukrainistycznych pewien skutek uboczny. Wycofanie ze szkół podstawowych i średnich obowiązku nauki języka rosyjskiego sprawiło, że już w pierwszej dekadzie XXI wieku na ukrainistykę zaczęły przychodzić osoby nieznające nawet cyrylickiego alfabetu, co wyraźnie spowalniało proces nauki języka. Wykorzystywanie w pracy dydaktycznej większej liczby przekładów stawało się koniecznością.

Po Stepowej legendzie następuje półtorej dekady przerwy. Ukraińska literatura współczesna jest $\mathrm{w}$ tym okresie nieustannie thumaczona i wydawana przez rozpoznawalne polskie wydawnictwa (Czarne, W.A.B, Biuro Literackie, Kolegium Europy Wschodniej, Krytyka Polityczna i inne), jednak proces przyswajania polszczyźnie ,przeoczonych” w polskiej recepcji dzieł dawniejszych znów zostaje zawieszony.

Obecnie mamy do czynienia z pewnym przełomem. Niemal równolegle realizowane są trzy duże projekty badawcze i wydawnicze dotyczące właśnie literatury lat dwudziestych i trzydziestych XX wieku, czyli tej najmniej dotychczas obecnej w polskiej recepcji.

W roku 2015 w Instytucie Badań Literackich PAN, dzięki grantowi NCN, rozpoczął się projekt „Polska i ukraińska proza kobieca okresu międzywojennego - perspektywa modernizmu (środkowo)europejskiego", kierowany przez Grażynę Borkowską i Olę Hnatiuk. Jednym z jego efektów jest antologia ukraińskiej małej prozy kobiecej Modernistki ${ }^{13}$, na którą składają się opowiadania, felietony i szkice piętnastu autorek.

Dwa kolejne projekty realizowane są obecnie, w latach 2018-2022, w ramach grantów NPRH, przyznanych w programie „Uniwersalia”. Ich celem jest opracowanie i wydanie w polskich przekładach trzech tomów dzieł Wiktora Petrowa ${ }^{14}$ oraz czterech tomów dzieł Mykoły Chwylowego. Projektami kierują, odpowiednio, Paweł Krupa oraz Iwona Boruszkowska ${ }^{15}$.

13 Modernistki. Antologia ukraińskiej prozy kobiecej okresu międzywojennego, red. G. Borkowska, I. Boruszkowska, K. Kotyńska, Warszawa 2017. Autorką wstępu do tego wydania jest O. Hnatiuk. Równolegle po ukraińsku ukazała się antologia tekstów pisarek polskich: Модерністки. Антологія польської жіночої прози міжвоєнного періоду, red. O. Hnatiuk, K. Kotyńska, I. Boruszkowska, Львів 2018.

${ }^{14}$ Znanego także jako Wiktor Domontowycz i Wiktor Ber.

15 Warto dodać, że jednocześnie w Instytucie Teatralnym im. Zbigniewa Raszewskiego realizowany jest jeszcze jeden projekt NPRH, „Odzyskana awangarda. Polska i środkowoeuropejska awangarda teatralna", w którego ramach ukaże się między innymi obszerny tom tekstów wybranych ukraińskiego reżysera i teoretyka teatru Łesia Kurbasa. 


\section{Skąd zmiana?}

Można by sądzić, że to zwykły badawczy zbieg okoliczności. Moim zdaniem jest to jednak wynik nagromadzenia pewnej trudno mierzalnej masy krytycznej sił, zasobów i możliwości.

Przede wszystkim Ukraina jako państwo, a co za tym idzie literatura ukraińska stały się w polskim odbiorze naturalnym elementem pejzażu geopolitycznego i kulturalnego, a także koniecznym — i interesującym — punktem odniesienia w dyskusjach o własnej, polskiej tożsamości i kulturze. Ćwierć wieku obecności informacji dotyczących Ukrainy w środkach masowego przekazu i dostępności książek ukraińskich autorów na półkach księgarń, łatwość przekraczania granicy (w porównaniu ze stanem wcześniejszym) zdecydowanie umocniły pozycję tego kraju na polskiej mapie mentalnej, łatwiej więc wyobrazić sobie i uzasadnić — na przykład we wniosku grantowym — konieczność udostępnienia Polakom tekstów, które wcześniej wypadły z pola naszego widzenia.

Druga istotna kwestia wiąże się z tym, że łatwiej uzupełniać istniejącą strukturę lub ją krytykować, niż wypełniać pola białych plam. Dzięki wielu realizowanym w ciągu minionego ćwierćwiecza projektom badawczym zwyczajnie o wiele więcej wiemy ${ }^{16}$. Na przykład w przygotowaniu antologii Modernistki uczestniczyło grono ukraińskich i polskich naukowczyń, które od kilku lat konsekwentnie badają i udostępniają twórczość pisarek okresu międzywojennego, między innymi Nadija Poliszczuk, Marjana Komarycia, Sylwia Wójtowicz-Marszał, Natalia Maftyn. Z kolei konferencja „Wiktor Petrow-Domontowycz - mapowanie twórczości pisarza" ${ }^{17}$ zgromadziła kilkudziesięciu specjalistów, głównie z Ukrainy, ale też z Polski, Niemiec, USA, którzy prezentowali wyniki swoich badań. Istnienie takiego zaplecza intelektualnego sprawia, że przygotowanie polskiego wydania krytycznego, pozostając ogromnym wyzwaniem, jest naturalnym kolejnym krokiem, a nie wołaniem na puszczy.

Oprócz zmiany mentalnej wśród polskich potencjalnych odbiorców oraz postępu merytorycznego po stronie potencjalnych autorów (edytorów, thumaczy, wydawców itp.) nastąpiła istotna zmiana infrastrukturalna. Powstał program NPRH „Uniwersalia”, którego celem jest właśnie edycja, tłumaczenie i wydanie głównych dzieł światowej humanistyki — wcześniej istniejące programy Narodowego Centrum Nauki zasadniczo nie obejmowały tego rodzaju działań. Wydanie obu tomów Modernistek w ramach grantu NCN stało się możliwe dzięki determinacji jego kierowniczek i precyzji sporządzonego przez nie uzasadnienia.

Mimo tych wszystkich zmian praca nad udostępnianiem polskim odbiorcom najważniejszych dzieł literatury ukraińskiej lat dwudziestych i trzydziestych XX

16 Por. np. monografie i artykuły takich badaczy, jak Wira Ahejewa, Tamara Hundorowa, Leonid Briuchowecki, Marjana Hirniak, Ołena Hałeta i Paweł Krupa.

17 „Wiktor Petrow-Domontowycz - mapowanie twórczości pisarza”, międzynarodowa konferencja naukowa, Kraków 6-7 czerwca 2019, zorganizowana w ramach grantu NPRH „Wiktor Petrow. W stronę krytycznej nowoczesności". 
wieku nadal napotyka różne problemy, w tym związane bezpośrednio z nowym systemem ewaluacji i parametryzacji polskich jednostek naukowych. To już nie wielka polityka, jak w minionych dekadach, tylko biurokracja różnych szczebli stawia przed badaczami i thumaczami najbardziej dokuczliwe przeszkody.

Przyjrzyjmy się bliżej podstawowej kwestii właściwego poziomu naukowego takich projektów. Polskie wydanie w wielu przypadkach nadal wymaga wykonania edycji tekstu, redakcji naukowej i stworzenia pionierskiego komentarza faktograficznego i historycznoliterackiego. Oznacza to bezwzględną konieczność tworzenia zespołów interdyscyplinarnych, złożonych z badaczy reprezentujących różne jednostki naukowe. Tymczasem taka współpraca nie wpływa na ocenę jednostki, którą reprezentuje osoba zaproszona spoza miejsca afiliacji grantu. Efekty bywają karykaturalne: naukowiec przez trzy lata pracuje nad ważnym i ciekawym projektem, publikuje, redaguje, zarządza zespołem międzynarodowym i realizuje wiele innych działań opisywalnych w kategoriach „punktów”, ale jego macierzysta instytucja (w kontekście ewaluacji i parametryzacji) nie ma z tego zupełnie nic. Tak samo groteskowe jest, że przekład literacki, choćby najbardziej wymagający, w ogóle nie liczy się jako „dorobek naukowy”.

Równie kłopotliwa jest konieczność prowadzenia pracy w „sekwencjach grantowych". Granty pozwalają na względnie komfortowe skupienie się na wybranym problemie badawczym. Wymuszają jednak radykalną segmentację działalności naukowej. Ograniczenia narzucane przez system sprawiają, że natychmiast po zakończeniu grantu wykonawcy robią „,w tył zwrot” i pospiesznie oddalają się do kolejnych wniosków i terminów sprawozdawczych. Byłoby to zabawne, ale jest to tylko symptom znacznie poważniejszego niebezpieczeństwa.

Uważam bowiem, że charakterystyczny dla humanistyki proces narastania i gromadzenia wiedzy wokół pewnych projektów, zjawisk, idei przy takim trybie pracy niebezpiecznie się osłabia. Jest to wszak zjawisko niemierzalne w kategorii „punktów” i dostrzegalne dopiero w znacznie szerszej perspektywie czasowej, gdy z pozornie niepowiązanych, rozproszonych działań, niekoniecznie „naukowych" w rozumieniu systemu punktacji i cytowań, tworzy się masa krytyczna bazy tekstowej oraz bazy wiedzy, która pozwala myśleć o dalszym rozwoju. Nie byłoby Modernistek bez badań nad ukraińskim modernizmem, prowadzonych przez naukowców z całego świata, ale nie byłoby ich także bez pozornie marginalnej Stepowej legendy, „,nienaukowej” lwowskiej serii wydawniczej „Prywatna Kolekcja" Wasyla Gabora i innych popularyzatorskich publikacji, bez polskich i ukraińskich recenzji prasowych, dyskusji publicznych, spotkań literackich oraz wielu innych, często efemerycznych projektów i wydarzeń, niekoniecznie wprost związanych z okresem modernizmu. Takie działania przyczyniają się do rekonstruowania i rozszerzania ram ukraińskiej pamięci zbiorowej, a po stronie polskiej pomagają rozszerzać ramy myślenia o ukraińskiej historii czy kulturze i ich znaczeniu dla wspólnej polskiej i ukraińskiej pamięci.

Pamięć nie poddaje się systemom nakazowo-rozdzielczym, nie da się jej zadekretować, czego dowodzi choćby przeciwskuteczność propagandy wydawniczej 
okresu PRL. Pamięć zbiorową można tylko ostrożnie wspierać i stymulować. Najbardziej efektywne w dłuższej perspektywie sposoby nie pasują do sprawozdawczych tabelek i nie dają się przeliczyć na żadne „punkty”. Tymczasem tylko od poszczególnych badaczy zależy, w jakim stopniu zdołają uciec od preferowanej przez system grantowy (być może mimowolnie) oraz nowy system oceny działalności naukowej (niestety bardzo konsekwentnie) „produkcji osiągnięć naukowych", a także czy uda im się uniknąć zamknięcia w odseparowanych od siebie zespołach, tworzonych zgodnie z afiliacją, a nie merytoryczną potrzebą. Skupienie na „czystej nauce” i ,wykonaniu planu” może niestety, po raz kolejny w historii, zdławić w zarodku tak dobrze zapowiadające się nowe możliwości pogłębienia obrazu literatury ukraińskiej w polskim odbiorze.

\section{Bibliografia}

Galeta O., Vìd antologï do ontologï: antologîa âk sposìb reprezentacï ukraïns'koï literaturi kìncâ XIX-počatku XXI stolittâ, Smoloskip, Kiïv 2015.

Gnatûk O. [O. Hnatiuk], Modifikovana recepciâ. Vidavniča praktika komunističnoï Pol'sì ta obraz ukraïns'koï kul'turi, [w:] eadem, Miž literaturoû ì politikoû. Eseï ta intermedï̈, Duh ì lìtera, Kiïv 2012.

Gnatûk O. [O. Hnatiuk], Ostrìvcì v okeanì. Pro recepcîu ukraïns'koï literaturi v pol's'kij kul'turì peršoï polovini XX stolittâ, [w:] eadem, Miž literaturô̂ ì politikô̂. Eseï ta intermedï, Duh ì litera, Kiïv 2012.

Hałeta O., Historia literatury jako praktyka ponownego czytania, [w:] Wspólnota wyobrażona. Pisarki Europy Środkowej wobec problemów literackich, spolecznych i politycznych lat 19141945, red. G. Borkowska, I. Boruszkowska, K. Nadana-Sokołowska, IBL, Warszawa 2017.

Kotyńska K., Na tropie pisarek. Wspótczesny kanon a literatura ukraińska między dwiema wojnami, [w:] Wspólnota wyobrażona. Pisarki Europy Środkowej wobec problemów literackich, spolecznych i politycznych lat 1914-1945, red. G. Borkowska, I. Boruszkowska, K. Nadana-Sokołowska, IBL, Warszawa 2017.

Krupa P., „Na Zachód” $i$,Z dala od Moskwy”? Publicystyka Mykoły Chwylowego lat 1925-1926. Historia - idee - konteksty, Universitas, Kraków 2018.

Litwiniuk J., Problemy przekładu z literatury ukraińskiej. Z warsztatu tlumacza, „Warszawskie Zeszyty Ukrainoznawcze" 1994, nr 2.

Modernistki. Antologiâ pol's'koï žinočoï prozi mižvoênnogo perìodu, red. O. Hnatiuk, K. Kotyńska, I. Boruszkowska, Vidavnictvo Starogo Leva, L'vìv 2018.

Modernistki. Antologia ukraińskiej prozy kobiecej okresu międzywojennego, red. G. Borkowska, I. Boruszkowska, K. Kotyńska, IBL PAN, Warszawa 2017.

Pavličko S., Diskurs modernizmu v ukraïns'kij literaturì, Libìd', Kï̈v 1997.

Pavlišin M., Kanon ta ikonostas, Čas, Kiïv 1997.

Samczuk U., Wotyń, Rój, Warszawa 1938.

Socjologia literatury. Antologia, red. G. Jankowicz, M. Tabaczyński, Ha!art, Kraków 2015.

Stepowa legenda. Antologia ukrainskiej małej formy prozatorskiej lat 1890-1930, red. O. Hnatiuk, L. Szost, SOW, Warszawa 2001.

Ukraińskie życie kulturalne na ziemiach II Rzeczypospolitej, red. O. Hnatiuk, K. Kotyńska, SOW, Warszawa 2002.

Żyłko B., O kłopotach badacza literatury rosyjskiej XX wieku uwag kilka, [w:] Literatura rosyjska XX wieku. Nowe czasy. Nowe problemy, red. G. Bobilewicz-Bryś, A. Drawicz, SOW, Warszawa 1992.

Slavica Wratislaviensia 173, 2020

(C) for this edition by CNS 


\section{Reconstruction of Memory. Problems of Sharing the Translations of Ukrainian Prose of the 1920s and 1930s with Polish Readers}

\section{Summary}

In the 1920s and 1930s novels and short stories crucial for understanding Ukrainian culture of the 20th century were written and published both in Soviet Ukraine and in Galicia. Such literary texts are essential in creating a comprehensive picture of Ukraine, as well as the Ukrainian-Polish relations. Because of politics and history, literary texts of the mature Ukrainian modernism were almost entirely unavailable in Polish translations. This paper discusses key historical, cultural and political reasons that have caused this situation. It also presents the new Polish scholarly and publishing projects aiming to familiarize Polish readers with Ukrainian modernism. In the conclusion, the author of the article mentions the current problems hindering the publication of the key Ukrainian novels and short stories of the 1920-1930s in Polish translations.

Keywords: collective memory, Polish-Ukrainian relations, sociology of literature, history of reception, literary translation

\section{Реконструювання пам'яті. Проблеми доступності перекладів української прози 1920-1930 рр. для польського читача}

Резюме

У 1920-1930-х рр. як у Радянській Україні, так і в Галичині, з'являються літературні прозові твори, ключові для розуміння української культури ХХ ст. та для творення колективної української пам'яті. Разом з тим, вони необхідні для творення у Польщі повноцінного образу українського сусіда та українсько-польських взаємин. Проте з історичних та політичних причин українська література вказаної епохи зрілого модернізму ще донедавна майже не була доступна у польських перекладах. Ця стаття подає аналіз основних історичних, культурних та політичних причин такого відставання; обговорюються також нові польські видавничі проекти (від 2015 р.), які допомагають заповнювати прогалини. У підсумках названо основні сучасні проблеми, які ускладнюють творення корпусу польських перекладів української прози вказаного періоду.

Ключові слова: колективна пам'ять, українсько-польські взаємини, соціологія літератури, історія рецепції, літературний переклад

Slavica Wratislaviensia 173, 2020

(C) for this edition by CNS 